\title{
Nutrient Solution Temperature Affects Pythium Root Rot of Tobacco in Greenhouse Float Systems
}

\author{
B. A. Fortnum, Professor of Plant Pathology and Physiology, Clemson University, Pee Dee Research and Educa- \\ tion Center, Florence, NC 29506-9706; J. Rideout, Assistant Professor of Soil Science, North Carolina State \\ University, Mountain Horticultural Crops Research and Extension Center, Fletcher 28732; S. B. Martin, Associate \\ Professor of Plant Pathology and Physiology, Clemson University, Pee Dee Research and Education Center; and D. \\ Gooden, Professor of Agronomy, Clemson University, Pee Dee Research and Education Center
}

\begin{abstract}
Fortnum, B. A., Rideout, J., Martin, S. B., and Gooden, D. 2000. Nutrient solution temperature affects Pythium root rot of tobacco in greenhouse float systems. Plant Dis. 84:289-294.

Float nutrient solution, soilless media, and ambient temperatures were monitored in two tobacco greenhouses with different heating regimes. Water temperatures at seeding were $11^{\circ} \mathrm{C}$ in an unheated greenhouse and $17^{\circ} \mathrm{C}$ in a heated greenhouse. Water temperature differences between greenhouses continued over the duration of seedling production. Media and air temperatures varied diurnally, but not float solution. In a greenhouse float system where water temperatures were constant at $15,20,25$, or $30^{\circ} \mathrm{C}$, seedling disease caused by Pythium myriotylum was correlated with float-water temperature and could be described by quadratic equations $\left(R^{2}=0.99\right)$ with the lowest level of root necrosis at $15^{\circ} \mathrm{C}$. Pythium spp.-infected and noninfected seedlings grown in controlled-temperature water baths were transplanted to the field and evaluated for disease development. Previous infection with $P$. myriotylum, regardless of float-temperature regime, failed to alter yield, leaf quality, or root necrosis $(P=0.05)$ in field-grown tobacco.
\end{abstract}

Greenhouse production of tobacco (Nicotiana tabacum) seedlings is replacing the traditional method of seedling production in outdoor seed beds (11). This interest in greenhouse production of transplants is driven by reduced labor requirements and production costs. The direct-seeded float system, where polystyrene seeding trays are filled with a soilless medium and then floated on a common nutrient solution bath (float bay), is the most widespread method of production. The float bay is covered completely by polystyrene trays, which provide an insulating seal between the heated greenhouse air and the water within the float bay. A lack of labeled pesticides to control common seedling diseases in this production system is a growing concern $(11,14)$.

Floating polystyrene seedling trays in a nutrient solution presents some unique challenges to controlling water molds, such as Pythium spp. Pythium spp. can spread by mycelium within the media or in water by motile, flagellate zoospores (16). Severe

Corresponding author: B. Fortnum

E-mail: bfrtnm@clemson.edu

Technical contribution No. 4385 of the South Carolina Agricultural Experiment Station. This research was supported in part by a grant from the RJ Reynolds tobacco company.

Accepted for publication 12 November 1999.

Publication no. D-2000-0120-02R

(c) 2000 The American Phytopathological Society
Pythium seedling blight has been observed in float systems in South Carolina and was limited by divisions within the float bays, suggesting that zoospores were the primary method of spread between trays (2).

In ebb-and-flow irrigation systems, $P$. aphanidermatum was more consistently transmitted when inoculum was present in the irrigation solution than when added to the growing medium within the irrigation system $(15,17,18)$. The role of the nutrient solution in the spread of Pythium spp. has been confirmed in other hydroponic systems, such as trough culture and the nutrient-film method (13). The role of temperature in the development of Pythium root rot is also well documented $(1,3,22)$. In hydroponic culture of spinach, $P$. aphanidermatum and $P$. dissotocum alternated in prominence based on temperature of the nutrient solution and the crop season $(5,10)$. Disease was minimized by management of the temperature of the nutrient solution (5).

The objectives of these studies were to determine the temperature regimes present in commercial greenhouse float-production systems; the role of float nutrient-solution temperature in Pythium seedling disease; and the effect of $P$. myriotylum infection of greenhouse-grown tobacco seedlings on Pythium root rot in field plantings.

\section{MATERIALS AND METHODS}

Greenhouse float-bay microclimate. The temperature of the greenhouse float water, soilless medium within polystyrene seeding trays, and ambient air $3 \mathrm{~cm}$ above the soil surface was recorded in two tobacco float greenhouses, one each in Florence and Horry Counties, South Carolina. Polystyrene seeding trays containing soilless medium (Carolina's Choice Tobacco Mix, Carolina Soil Company, Kinston, NC) were seeded with pelletized tobacco seed of tobacco cv. K 149. At site 1, float bays were filled with nutrient solution and trays were placed immediately upon the unheated nutrient solution after seeding. At the completion of seeding, the greenhouse was heated according to Clemson Extension recommendations (14). At site 2, nutrient solution was placed within the float bay, the greenhouse ventilation curtains were closed, and the greenhouse was heated $72 \mathrm{~h}$ prior to seeding and placement of trays on the nutrient solution. The water within the float bay was heated by convection and solar radiation. Sites 1 and 2 were seeded on 22 January and 2 February 1997, respectively.

Temperatures in each greenhouse were monitored after completion of seeding with Campbell 21X Microloggers (Campbell Scientific, Logan, UT) with copper-constantan fixed thermocouples. Three thermocouples were wired in parallel to a common lead and dispersed $>1 \mathrm{~m}$ apart within the float bay. Temperatures were averages for nine readings (three replications $\times$ three thermocouples/replication). Temperature values at seeding for each micrologger were confirmed with an Omega digital thermometer (Model $\mathrm{HH}-$ 25TC, Omega Engineering, Stanford, CT) Temperatures were recorded every $10 \mathrm{~min}$ and averaged for each 60 -min period. Fertility and insect control were based on Clemson University Extension recommendations $(11,14)$.

Controlled water-temperature experiments. Pythium seedling disease was evaluated in a greenhouse float-seedling production system where float nutrientsolution temperatures were held constant at $15,20,25$, and $30^{\circ} \mathrm{C}$. Float bays $(30 \mathrm{~cm}$ long by $22 \mathrm{~cm}$ wide by $12 \mathrm{~cm}$ deep) with a 5-liter capacity were constructed from stainless steel, lined with black polyethylene plastic, and placed within Wisconsin water temperature tanks (WWTT). Water temperature within the WWTT was controlled $\left( \pm 1^{\circ} \mathrm{C}\right)$ with digital two-stage controllers (Independent Energy Inc., East 
Greenwich, RI). Polystyrene 288-cell seedling trays (Speedling, Sun City, FL) were cut with a bandsaw to form miniature trays 22 $\mathrm{cm}$ long by $18 \mathrm{~cm}$ wide by $8 \mathrm{~cm}$ deep containing 48 cells each. Air temperature within the greenhouse was maintained between 20 and $28^{\circ} \mathrm{C}$. Water used in the miniature float bays was filtered through a deionizing column (Barnstead Combination Column, Barnstead/Thermolyne, Dubuque, IA) and tested for ionic and bicarbonate content (Clemson University Agricultural Services Laboratory, Clemson, South Carolina).

Soilless medium was covered with a polyethylene tarp and fumigated with methyl bromide $\left(0.1 \mathrm{~kg} / 0.2 \mathrm{~m}^{3}\right)$. The tarp was removed $48 \mathrm{~h}$ after fumigation and residual fumigant allowed to escape over a 14-day period. Trays were filled with soilless medium ( $\mathrm{pH}$ 5.6) and seeded with pelletized tobacco seed (cv. K 326) using a vacuum seeder. Plants were grown for 4 weeks prior to inoculation with Pythium spp. Water temperature within each miniature float bay was within $\pm 1{ }^{\circ} \mathrm{C}$ of the water within the WWTT. Nutrients $\left(250 \mathrm{mg} \mathrm{l}^{-1}\right.$ of $\mathrm{N}$ supplied as $50 \% \mathrm{Ca}\left(\mathrm{NO}_{3}\right)_{2}$ and $50 \%$ $\mathrm{Mg}\left(\mathrm{NO}_{3}\right)_{2}, 36 \mathrm{mg} \mathrm{l}^{-1}$ of $\mathrm{P}$ supplied as $\mathrm{KH}_{2} \mathrm{PO}_{4}$, and $208 \mathrm{mg} \mathrm{l}^{-1}$ of $\mathrm{K}$ supplied as $33 \% \mathrm{KH}_{2} \mathrm{PO}_{4}$ and $67 \% \mathrm{~K}_{2} \mathrm{SO}_{4}$ ) were added to each float bay 14 days after seeding.

Table 1. Source of variation and probability values for main effects and interactions of temperature and fungal inoculation on disease caused by Pythium myriotylum and plant-growth parameters in tobacco seedlings grown in a greenhouse float-production system

\begin{tabular}{lccc}
\hline & \multicolumn{3}{c}{$\boldsymbol{P}>\boldsymbol{F}$ values $^{\mathbf{a}}$} \\
\cline { 2 - 4 } Source of variation & Root-necrosis index & Root-growth index & Shoot weight (g) \\
\hline Trial 1 & $* * *$ & $* *$ & $*$ \\
Temperature (Temp) & $* * *$ & $* * *$ & $* * *$ \\
Fungus inoculation (Inoc) & $* * *$ & $* * *$ & $* * *$ \\
Temp $\times$ Inoc & & & $* *$ \\
Trial 2 & $* * *$ & $\mathrm{~ns}$ & $(0.06)$ \\
Temp & $* * *$ & $* * *$ & $* *$ \\
Inoc & $* * *$ & $* * *$ & \\
Temp $\times$ Inoc & & & \\
\hline
\end{tabular}

${ }^{\text {a }}$ ns $=$ not significant at $P=0.05 ; *$ at $P=0.05 ; * *$ at $P=0.01$; and *** at $P=0.001$.

February $15-24$
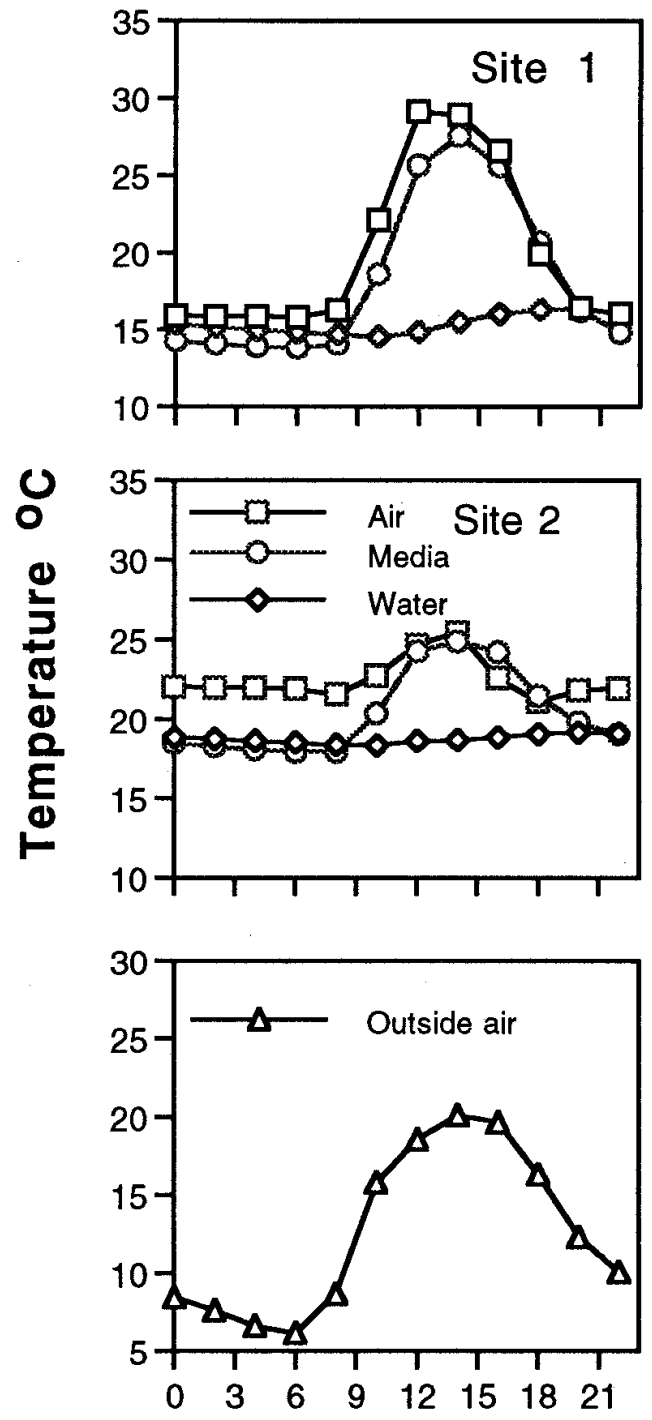

Hour
March 6-15
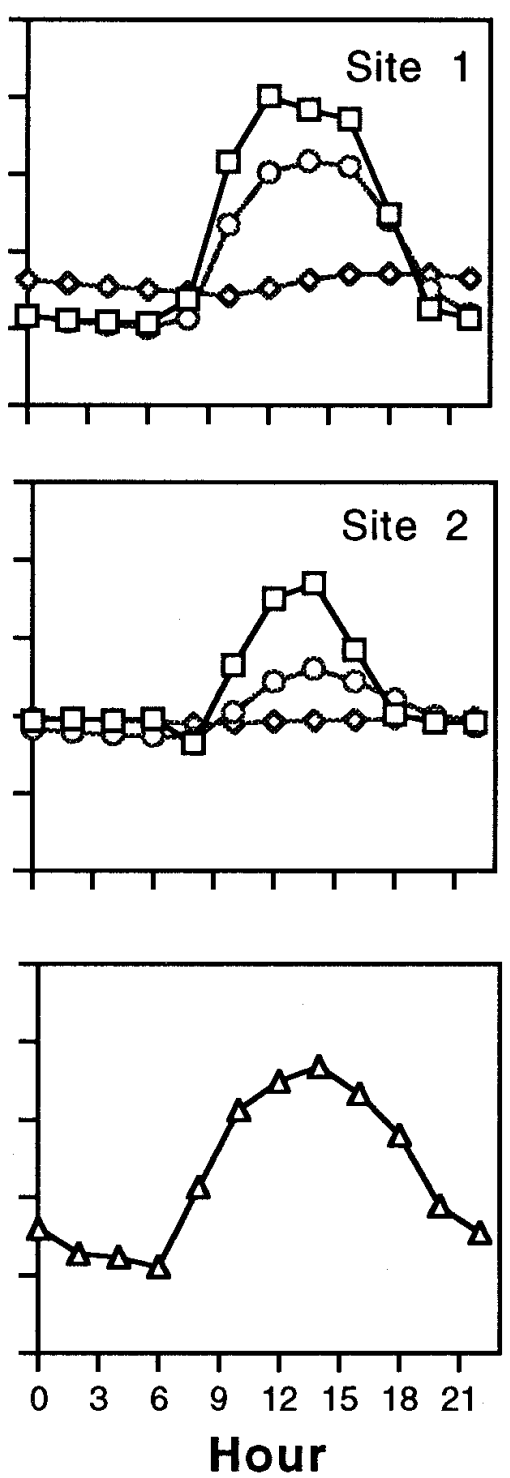

March 24 - April 3
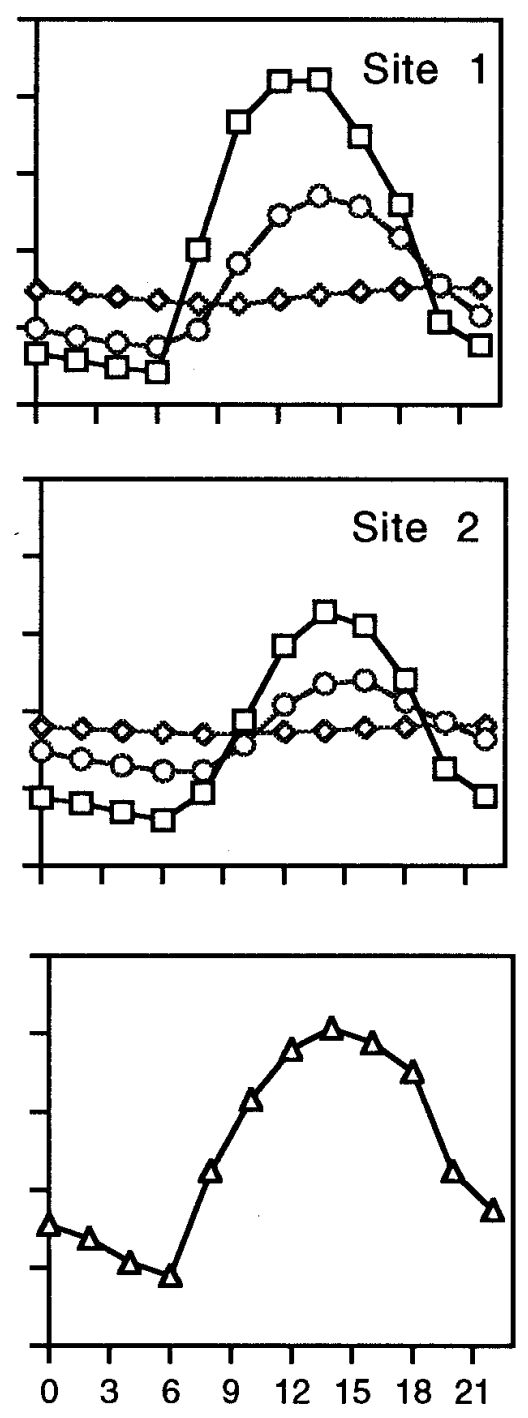

Hour

Fig. 1. Float nutrient solution, soilless media, and interior and exterior air temperatures in two greenhouse float systems where greenhouse air was unheated (site 1 ) or heated $72 \mathrm{~h}$ prior to seeding (site 2 ). 
P. myriotylum was isolated from a diseased tobacco seedling in a greenhouse float system in Walterboro, South Carolina and cultured on V 8 agar (8). Rye grass leaf blades were placed in 250-ml flasks at a 1:10 (wt/vol) dilution in distilled water, autoclaved for $45 \mathrm{~min}$ at $145 \mathrm{kPa}$ and $120^{\circ} \mathrm{C}$, and cooled, after which the procedure was repeated. $P$. myriotylum was transferred on a colonized agar block to cooled, sterilized leaf blades and incubated for 1 week at 21 to $23^{\circ} \mathrm{C}$ before use as inoculum. Float water was infested with 1 $\mathrm{g}$ (fresh weight) of rye grass by placing infested leaf blades directly in the nutrient solution of the miniature float bay. Rye grass is frequently used to stabilize soil around recently constructed greenhouses and as a winter cover, and is a likely source of organic matter within float water. Control plants received rye grass blades free of
P. myriotylum
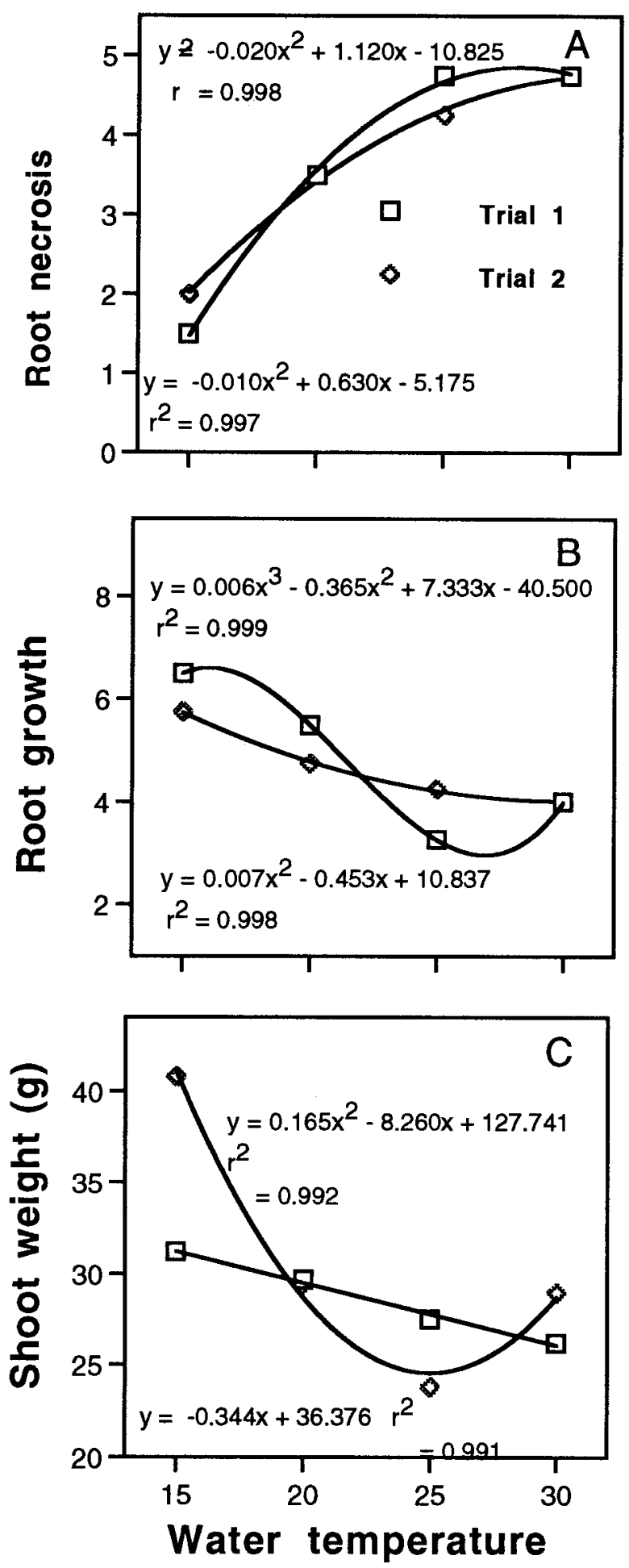

Non-Inoculated Control
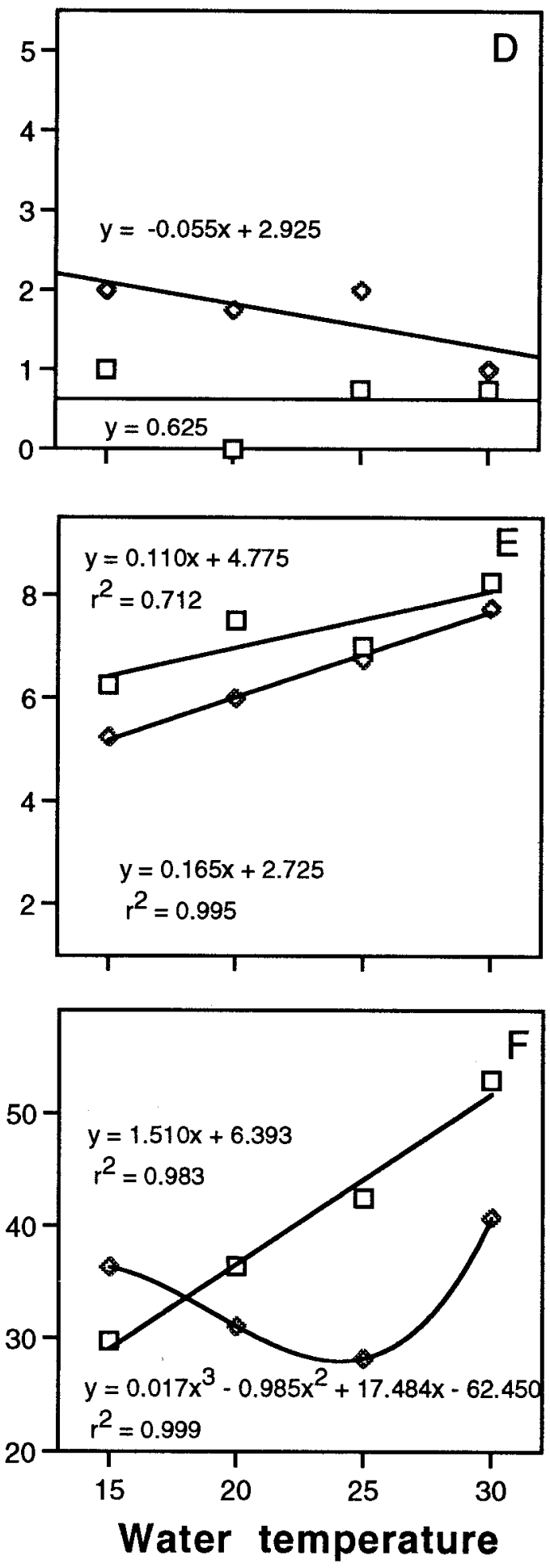

Fig. 2. Shoot weight, root-growth index, and root necrosis of tobacco seedlings grown in a greenhouse float system where the float nutrient solution was (A-C) infested with Pythium myriotylum or (D-F) noninfested and nutrient solution temperatures were constant at $15,20,25$, or $30^{\circ} \mathrm{C}$ Trial $1=\square$ and Trial $2=\diamond$. Regressions based on means. 
Pythium spp. that had been treated in a similar fashion. were evaluated 7, 14, and 21 days following infestation of the float water. Root necrosis was rated on a 0-to-5 linear scale, where $0=$ white, near-translucent root tissue that is turgid, with no brown discoloration (necrosis); $1=$ trace to $20 \%$; $2=21$ to $40 \% ; 3=41$ to $60 \% ; 4=61$ to $80 \%$; and $5=81$ to $100 \%$ of the root tissue brown in color, with a loss of turgor. Root vigor was rated on a 0-to-10 linear scale, where $0=$ no visible root growth following inoculation and a collapse of existing roots; $1=1$ to $10 \% ; 2=11$ to $20 \% ; 3=21$ to $30 \% ; 4=31$ to $40 \% ; 5=41$ to $50 \% ; 6=$ 51 to $60 \% ; 7=61$ to $70 \% ; 8=71$ to $80 \%$; $9=81$ to $90 \%$; and $10=91$ to $100 \%$ of seedling roots with healthy, vigorous roots, extensive lateral branching, and root length $\geq 15 \mathrm{~cm}$.

A total of 10 root systems were randomly selected from each tray. Roots were washed free of soilless mix by rinsing in tap water and separated into proximal (within the soilless medium plug) and distal (extending out into the float water) portions for a total of 20 root pieces per tray. Root pieces were surface sterilized in $70 \%$ ethanol for 10 to $15 \mathrm{~s}$, rinsed twice in sterile distilled water, blotted on sterile paper towels, and placed on Pythium spp.selective medium $\mathrm{P}_{5} \mathrm{ARP}$ (12). Root pieces were incubated for 2 days at 21 to $23^{\circ} \mathrm{C}$ and the number of proximal and distal infected root pieces recorded.

A randomized complete block factorial design was used with four replications per
Plant growth and disease development

trial and the trial was repeated once. Data were analyzed using analysis of variance (ANOVA) and regression techniques (19) by JMP and MACSAS (Statistical Analysis System, SAS Institute, Cary, NC).

Field experiments. Tobacco seedlings (cv. K 326) from the controlled water-temperature experiments were used in these studies. Both test sites were located at the Pee Dee Research and Education Center, Florence, South Carolina, on a Norfolk sandy loam soil (75\% sand, $17 \%$ silt, $8 \%$ clay, $0.8 \%$ organic matter, $\mathrm{pH}$ 5.9) which had been fallow the preceding year. Disk harrowing and in-row subsoiling $35 \mathrm{~cm}$ deep preceded all treatments. A total of 20 seedlings were randomly selected from tray cells within each simulated float bay from the previous experiments and transplanted into test plots consisting of single rows, $12.2 \mathrm{~m}$ long with a $1.2-\mathrm{m}$ row spacing, on 24 April and 1 June 1997, respectively. All treatments were replicated four times with main plots as float-water temperature and subplot effects as Pythium spp. inoculation. The tobacco was maintained using standard agronomic practices (11), with the exception that no nematicide or fungicide was applied and the plots were not replanted to replace missing plants. The plots received irrigation as needed. Mature leaves from all plots were harvested, cured, and weighed. Cured leaf was rated for quality by United States Department of Agriculture government graders and a quality index calculated (6). At the last harvest, 10 plants from each plot row were excavated at random and the root systems rated for Meloidogyne incognita

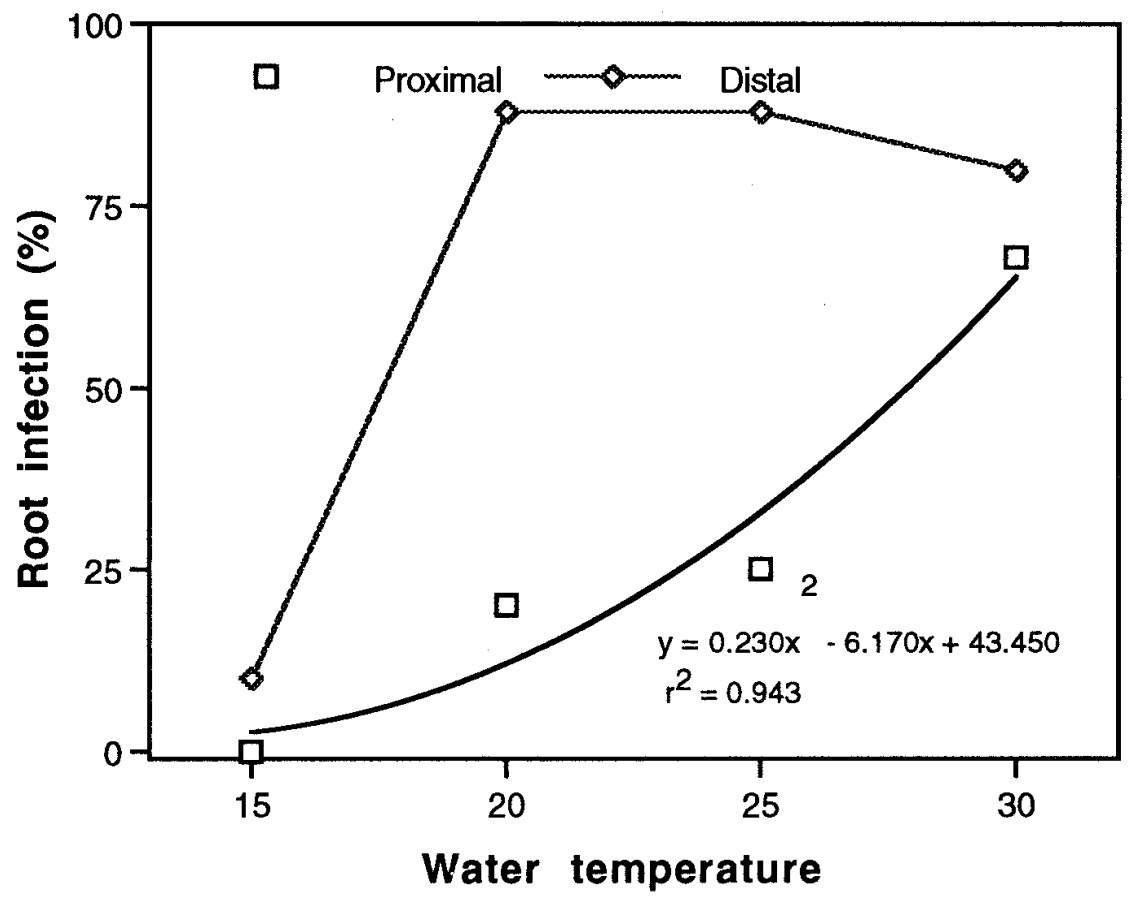

Fig. 3. Percent of proximal ( $\square=$ within the soilless medium) and distal ( $\diamond=$ extending out into the float water) roots infected with Pythium myriotylum in a greenhouse float system where the floatwater temperature was held constant at $15,20,25$, or $30^{\circ} \mathrm{C}$. Regressions based on means from trial 1 .
(Kofoid \& White) Chitwood-induced root galling (0-to-10 scale, where $0=$ no galls, $1=1$ to $10 \%, 2=11$ to $20 \%, 3=21$ to $30 \%, 4=31$ to $40 \%, 5=41$ to $50 \%, 6=51$ to $60 \%, 7=61$ to $70 \%, 8=71$ to $80 \%, 9=$ 81 to $90 \%$, and $10=91$ to $100 \%$ of the root tissue galled) and necrosis (0-to-5 scale, where $0=$ no necrosis, $1=$ trace to $20 \%, 2$ $=21$ to $40 \%, 3=41$ to $60 \%, 4=61$ to $80 \%$, and $5=81$ to $100 \%$ of the root tissue brown in color) (4).

\section{RESULTS}

Greenhouse float-bay microclimate. Float nutrient-solution temperature at seeding was higher in the heated greenhouse $\left(17^{\circ} \mathrm{C}\right)$ than in the unheated greenhouse $\left(11^{\circ} \mathrm{C}\right)$. Polystyrene seeding trays formed an insulating barrier between the heated air and the nutrient solution and water temperatures remained lower at site 1 than site 2 throughout the experiment (Fig. 1). Soilless medium and air temperatures varied diurnally, but not the nutrient solution (Fig. 1). The temperatures of the medium within a seeding tray, during periods of peak solar radiation (hour 9 to 18), were similar (15 to 25 February) to the ambient air temperatures $3 \mathrm{~cm}$ above the soil surface (Fig. 1). Water temperature at completion of seedling production was $17.7^{\circ} \mathrm{C}$ for site 1 and $19.5^{\circ} \mathrm{C}$ for site 2 . Seedlings were used for field production from both greenhouse systems.

Controlled water-temperature experiments. When solution temperatures were held constant at $15,20,25$, or $30^{\circ} \mathrm{C}$, Pythium seedling blight progressed from no detectable root necrosis 7 days after inoculation to severe root necrosis at 21 days. The root-necrosis index, root-growth index, and shoot weight were altered by float solution temperature $(T)$ and fungus inoculation $(F)$, and $T \times F$ interactions were observed for all plant-growth parameters and root-necrosis index $(P \leq 0.01$; Table 1).

Seedling root necrosis caused by $P$. myriotylum increased with float-solution temperature and could be described by a quadratic equation $\left(R^{2}>0.99\right.$ at both sites, $P<0.05)$, with the lowest level of root necrosis at $15^{\circ} \mathrm{C}$ and the highest at $30^{\circ} \mathrm{C}$ (Fig. 2). Root growth of inoculated plants was negatively correlated with float-solution temperature and could be described by cubic and quadratic relationships $\left(R^{2}>\right.$ 0.99 at both sites), respectively $(P \leq 0.05)$. Root growth generally increased in a linear fashion with increasing float-solution temperature in noninoculated float bays $\left(R^{2}=\right.$ 0.71 and 0.99 , respectively; Fig. 2). Shoot weight of inoculated plants was negatively correlated with float-water temperature and could be described by linear and cubic relationships $\left(R^{2}>0.99\right.$ at both sites, $P \leq$ $0.05)$, respectively. Shoot weight increased in a linear fashion with increasing floatsolution temperature in noninoculated float bays for site $1\left(R^{2}=0.98\right)$ and a cubic re- 
lationship for site $2\left(R^{2}=0.99\right)$. Although higher float-solution temperatures generally increased root and shoot growth, seedlings from all noninoculated float bays were suitable for transplanting irrespective of float-solution temperature.

Root infection by $P$. myriotylum was influenced by float-solution temperature $(P<$ 0.001 ), root location (proximal versus distal; $P<0.001$ ), and a temperature $\times$ root location interaction was observed $(P=$ 0.01; trial 1, Fig. 3).

Field experiments. Neither float-solution temperature nor infestation with $P$. myriotylum altered cured-leaf yield, leaf quality, leaf value, or root necrosis in field tobacco in trial 1, but cured-leaf yield and value were lower $(P \leq 0.025)$ in tobacco grown from seedlings produced in float solution at $15^{\circ} \mathrm{C}$ than other temperatures in trial 2 (Table 2). Galling caused by rootknot nematodes was lower in plants grown in float solution infested with $P$. myriotylum relative to plants grown in noninfested solution $(P \leq 0.025$; Table 2$)$. Infestation of float solution with $P$. myriotylum did not alter yield, quality, value, or root necrosis in field tobacco grown from these seedlings (trial 2, $P=0.05$ ).

\section{DISCUSSION}

Many tobacco producers in South Carolina close the ventilation system and heat the interior of the greenhouse prior to seeding in order to heat the float solution. Warmer float solutions generally increased seedling shoot weight and root growth in our trials, but it may also increase the occurrence of Pythium seedling disease. Excellent seedlings also were produced in nonpreheated greenhouses, so preheating float water may not be necessary to produce high-quality transplants.

The severity of Pythium seedling disease increased as float solution temperatures increased above $15^{\circ} \mathrm{C}$. The first report of Pythium seedling disease in South Carolina (2) occurred in a greenhouse where the producer was attempting to grow a second crop of seedlings late in the spring. Ground and float water temperatures likely were higher later in the spring; therefore, an environment conducive for $P$. myriotylum may have favored development of the epidemic. Pythium disease is common in float bays late in the spring when greenhouses are partially emptied and uncovered bays gain heat from radiant energy.

Seedlings infected with $P$. myriotylum showed reduced shoot weight and were yellow and partially wilted. Although the seedlings recovered when planted in the field with no detectable loss in cured-leaf yields, the unthrifty appearance of the infected seedlings within the float bay would have reduced the value of the seedling in a commercial seedling production system.

Pythium spp. with lower cardinal temperatures, such as $P$. ultimum, have been found in commercial potting medium used for tobacco transplant production (7). $P$. ultimum causes disease in traditional seedbed production (16) and has been observed in other greenhouse production systems
(20). Although not previously observed in South Carolina float bays, Pythium spp. have been reported in other greenhouse systems $(7,10,15)$ and may cause damage in float systems when solution temperatures are less than $20^{\circ} \mathrm{C}$. Pythium spp. were recovered from roots in infested and noninfested float bays in trial 2. Fungus gnats (Bradysia impatiens) observed in trial 2 are a likely source of contamination with nonpathogenic Pythium spp. (9). Normally, greenhouse media for tobacco seedling production will have a resident microflora (7). Although the medium from trial 2 had a resident microflora of nonpathogenic Pythium spp., disease development in bays inoculated with $P$. myriotylum was identical in both trials. This suggests that the temperature of the float water is a key element in the development of Pythium seedling disease, with or without a resident microflora.

Greenhouse float-bed production of tobacco seedlings is common in the southeastern United States and is becoming more common in other tobacco-production areas of the world. Greenhouse float-seedling technologies in more tropical locations might increase the occurrence and severity of Pythium disease.

\section{LITERATURE CITED}

1. Adams, P. B. 1971. Pythium aphanidermatum oospore germination as affected by time, temperature, and pH. Phytopathology 61:11491150.

2. Anderson, M. G., Fortnum, B. A., and Martin, S. B. 1997. First report of Pythium myrioty-

Table 2. Yield, value, and quality of flue-cured tobacco grown from seedlings produced in a greenhouse float-production system where float water temperatures were controlled and float water was infested with Pythium myriotylum ${ }^{\mathrm{a}}$

\begin{tabular}{|c|c|c|c|c|c|c|}
\hline Solution temperature $\left({ }^{\circ} \mathbf{C}\right)$ & Inoculation & Yield (kg/ha) & Quality index ${ }^{b}$ & Value (\$/ha) & Root gall index ${ }^{\mathrm{c}}$ & Root necrosis index ${ }^{d}$ \\
\hline \multicolumn{7}{|l|}{ Trial 1} \\
\hline 15 & - & 3,360 & 44 & 12,627 & 1.2 & 1.1 \\
\hline 15 & + & 3,721 & 43 & 13,983 & 1.4 & 1.0 \\
\hline 20 & - & 3,368 & 43 & 12,523 & 1.2 & 1.0 \\
\hline 20 & + & 3,438 & 44 & 12,933 & 1.4 & 0.9 \\
\hline 25 & - & 3,312 & 46 & 12,508 & 1.4 & 1.0 \\
\hline 25 & + & 3,448 & 42 & 12,938 & 1.2 & 1.2 \\
\hline 30 & - & 3,284 & 43 & 12,281 & 0.8 & 0.9 \\
\hline 30 & + & 3,246 & 41 & 12,133 & 1.3 & 1.0 \\
\hline \multicolumn{7}{|l|}{$P>F$} \\
\hline Temperature (Temp) & $\ldots$ & $\mathrm{ns}$ & $\mathrm{ns}$ & $\mathrm{ns}$ & $\mathrm{ns}$ & $\mathrm{ns}$ \\
\hline P. myriotylum & $\ldots$ & ns & ns & ns & $\mathrm{ns}$ & ns \\
\hline Temp $\times$ P. myriotylum & $\ldots$ & ns & ns & $\mathrm{ns}$ & ns & $\mathrm{ns}$ \\
\hline \multicolumn{7}{|l|}{ Trial 2} \\
\hline 15 & - & 1,332 & 28 & 4,456 & 2.0 & 1.1 \\
\hline 15 & + & 1,032 & 26 & 3,572 & 1.1 & 1.1 \\
\hline 20 & - & 1,832 & 29 & 6,237 & 2.5 & 1.2 \\
\hline 20 & + & 1,931 & 30 & 6,570 & 2.4 & 1.2 \\
\hline 25 & - & 1,576 & 30 & 5,417 & 2.6 & 1.1 \\
\hline 25 & + & 1,612 & 27 & 5,441 & 2.0 & 1.2 \\
\hline 30 & - & 1,612 & 30 & 5,577 & 3.3 & 1.2 \\
\hline 30 & + & 1,556 & 24 & 5,254 & 1.8 & 1.1 \\
\hline \multicolumn{7}{|l|}{$P>F$} \\
\hline Temp & $\ldots$ & $* *$ & $\mathrm{~ns}$ & ** & $\mathrm{ns}$ & $\mathrm{ns}$ \\
\hline P. myriotylum & $\ldots$ & $\mathrm{ns}$ & ns & ns & ** & ns \\
\hline Temp $\times$ P. myriotylum & $\ldots$ & $\mathrm{ns}$ & ns & $\mathrm{ns}$ & ns & $\mathrm{ns}$ \\
\hline
\end{tabular}

a Significance indicated by * at $P=0.05$, ** at $P \leq 0.025$, and *** at $P \leq 0.01$.

${ }^{\mathrm{b}}$ Quality index based on government grade on a scale of 1 to 100 , where 100 is best.

${ }^{c}$ Root-knot nematode galling was rated from 0 to 10 on a linear scale, where $0=$ no galling and $10=100 \%$ of the root tissue galled.

${ }^{\mathrm{d}}$ Root necrosis was rated on a 0 to 5 linear scale, where $0=$ no necrosis and $5=100 \%$ of the root tissue necrotic. 
lum in a tobacco seedling float system in South Carolina. Plant Dis. 81:227.

3. Ayers, W. A., and Lumsden, R. D. 1975. Factors affecting production and germination of oospores of three Pythium species. Phytopathology 65:1094-1100.

4. Barker, K. R., Townshend, J. L., Byrd, G. W., Thomason, I. J., and Dickson, D. W. 1986. Determining nematode population responses to control agents. Pages 283-296 in: Methods for Evaluating Pesticides for Control of Plant Pathogens. K. D. Hickey, ed. American Phytopathological Society, St. Paul, MN.

5. Bates, M. L., and Stanghellini, M. E. 1982. Root rot of hydroponic-grown spinach caused by Pythium aphanidermatum and Pythium dissotocum. Plant Dis. 68:989-991.

6. Bowman, D. T., Tart, A. G., Wernesman, E. A., and Corbin, T. C. 1988. Revised North Carolina grade index for flue-cured tobacco. Tob. Sci. 32:39-40

7. Cartwright, D. K., Spurr, H. W., Jr., and Shew, H. D. 1995. Commercial potting medium as a source of Pythium causing disease on tobacco transplants. Plant Dis. 79:538.

8. Dhingra, O., and Sinclair, J. B. 1985. Basic Plant Pathology Methods. CRC Press, Inc.
Boca Raton, FL.

9. Gardiner, R. B., Jarvis, W. R., and Shipp, J. L. 1990. Ingestion of Pythium spp. by larvae of the fungus gnat Bradysia impatiens (Diptera: Sciaridae). Ann. Appl. Biol. 116:205-212.

10. Gold, S. E., and Stanghellini, M. E. 1985. Effects of temperature on Pythium root rot of spinach grown under hydroponic conditions. Phytopathology 75:333-337.

11. Gooden, D. T., Rideout, J. W., Christenbury, G. D., Loyd, M. I., Manley, D. G., Martin, S. B., and Stanton, L. A. 1992. South Carolina Tobacco Grower's Guide-1993. Coop. Ext. Circ. EC 569.

12. Jeffers S. N., and Martin, S. B. 1986. Comparison of two media selective for Phytophthora and Pythium species. Plant Dis. 70:1038-1043.

13. Jenkins, S. F., Jr., and Averre, C. W. 1983. Root diseases of vegetables in hydroponic culture systems in North Carolina greenhouses. Plant Dis. 67:968-970.

14. Rideout, J. W., Gooden, D. T., Christenbury, G. D., Fortnum, B. A., Manley, D. G., and Sutten, R. 1994. Tobacco transplant production in greenhouses. Clemson Univ. Coop. Ext. Circ. 682.
15. Sanogo, S., and Moorman, G. W. 1993 Transmission and control of Pythium aphanidermatum in an ebb-and-flow subirrigation system. Plant Dis. 77:287-290.

16. Shew, H. D. 1991. Pages 20-21 in: Compendium of Tobacco Diseases. G. Lucas and $\mathrm{H}$ D. Shew, eds. APS Press, St. Paul, MN

17. Stanghellini, M. E., and Rasmussen, S. L. 1994. Hydroponics a solution for zoosporic pathogens. Plant Dis. 78:1129-1138.

18. Stanghellini, M. E., White, J. G., Tomlinson, J. A., and Clay, C. 1988. Root rot of hydroponically grown cucumbers caused by zoospore-producing isolates of Pythium intermedium. Plant Dis. 72:358-359.

19. Steel, R. G. D., and Torrie, J. H. 1960. Principles and Procedures of Statistics. McGrawHill, New York.

20. Stephens, C. T., and Powell, C. C. 1982. Pythium species causing damping-off of seedling plants in Ohio greenhouses. Plant Dis. 66:731-733.

21. Thomson, T. VB., Athow, K. L., and Laviolette, F. A. 1971. The effect of temperature on the pathogenicity of Pythium aphanidermatum, $P$. debaryanum, and $P$. ultimum on soybean. Phytopathology 61:933-935. 